elzbieta.skubala@lib.p.lodz.pl

Matgorzata Rożniakowska-Kłosińska

mroz@lib.p.lodz.pl

Biblioteka Politechniki Łódzkiej

\title{
ROLA BIBLIOTEKI UCZELNIANEJ W TWORZENIU BAZY INFORMACYJNEJ SZKOLY WYŻSZEJ
}

\begin{abstract}
The universities are subjects of the continuous evaluation, not only in terms of their educational offer and the quality of research, but also in the commercialization of new technologies and their industry transfer. The research output, in the form of scientific publishing, being accessed via institutional repositories, is also taken under consideration and the university e-learning courses are the essential, too. The results of these evaluations are presented in the form of various rankings - domestic and international. The most recognized and important are: the "Perspectives" produced by the Educational Foundation, the report of the Ministry of Science and Higher Education and the Webometrics Ranking of World Universities.

The assumption, that soon the obtained results from such evaluation of the universities, will have the much more crucial influence on the budget resources and their allocation from public money, becomes the reality. The supporting tool named POL-on for the financial decision-making processes among others, is recently under implementation by the Ministry of Science and Higher Education. The procedure of input data delivery to this system by universities has been recently legalized by the reviewed act on the science financing.

Hence, in the current legal state, questions of the role of university library arise in terms of management the institutional repositories, bibliographic databases of the university scientific publications and research information systems.

Additionally, in the paper, the analysis of openness and resources type in Polish repositories registered in Ranking Web of World repositories, will be performed.
\end{abstract}

Słowa kluczowe: Zintegrowany System Informacji o Nauce i Szkolnictwie Wyższym POL-on, systemy zarządzania wiedzą, rankingi szkół wyższych

Rolę biblioteki akademickiej w systemie zarządzania wiedzą szkoły wyższej wyznacza między innymi konieczność gromadzenia, przetwarzania i przesyłania coraz większej liczby informacji i danych do różnych instytucji. Na podstawie tych danych uczelnie mogą być oceniane oraz porównywane.

W coraz większym stopniu funkcjonowanie szkół wyższych podlega konkurencji, w której jakość oferowanych usług jest istotnym elementem procesu oceny uczelni. Władze uczelni zwracają uwagę na dbałość o dobry wizerunek instytucji, właściwie prowadzony PR (public relations) i wykorzystują w tym 


\section{8}

celu dostępne narzędzia komunikacji ${ }^{1}$. Równolegle są zobowiązane do składania sprawozdań z działalności, poddawania się ocenom i pozyskiwania środków finansowych (w tym publicznych z dotacji budżetowej z Ministerstwa Nauki i Szkolnictwa Wyższego - MNiSW) na funkcjonowanie instytucji. MNiSW dysponując ograniczonymi środkami publicznymi musi je dzielić, opierając się na czytelnych i porównywalnych kryteriach. We wszystkie te procesy: promocję, sprawozdawczość i ocenę funkcjonowania uczelni jest zaangażowana również biblioteka.

Zarządzający szkołami wyższymi, raportując działalność placówek do różnych urzędów, korzystają z rozproszonych lokalnych baz, które dodatkowo w chwili obecnej nie zapewniają referencyjności. Pojawiła się potrzeba posiadania centralnej bazy informacyjnej, typu Current Research Information System - CRIS, gromadzącej dane statystyczne i zbierającej informacje wymagane przez różne instytucje oceniające. Budowa takiej bazy danych w dużych szkołach wyższych o rozbudowanej strukturze i w dużej części zdecentralizowanych finansowo jest działaniem skomplikowanym, zarówno technicznie jak i organizacyjnie. W Polsce niewiele uczelni posiada systemy zarządzania wiedzą. Na rynku jest dostępna oferta komercyjnych narzędzi (Converis, Office Objects). Podjęte zostały również działania zmierzające do budowy narzędzi własnych, na potrzeby konkretnej uczelni lub grupy szkół wyższych (OmegaPsir).

Niezależnie od działań wewnętrznych jednostek naukowych, MNiSW od kilku lat finansuje budowę narzędzia informatycznego o nazwie POL-on - Zintegrowany System Informacji o Nauce i Szkolnictwie Wyższym, którego zadaniem będzie wspieranie zarządzania nauką w Polsce. Narzędzie jest również przeznaczone dla wsparcia pracy Głównego Urzędu Statystycznego (GUS) oraz Centralnej Komisji do spraw Stopni i Tytułów (CKdsSiT).

Prace nad systemem rozpoczęły się $\mathrm{w}$ drugiej połowie $2010 \mathrm{r}$. i były współfinansowane przez Unię Europejską ze środków Europejskiego Funduszu Społecznego, w ramach programu Kapitał Ludzki 2007-2013 (priorytet IV, działanie 4, poddziałanie 4.1.3.) Narodowa Strategia Spójności.Zadania realizowały: Ośrodek Przetwarzania Informacji - Państwowy Instytut Badawczy, Ministerstwo Nauki i Szkolnictwa Wyższego, Interdyscyplinarne Centrum Modelowania Matematycznego i Komputerowego Uniwersytetu Warszawskiego oraz Index Copernicus International.

Wypełnianie danymi modułów systemu przez jednostki naukowe, w tym szkoły wyższe, wymagało obligacji ustawowej. Stąd, 5 września 2014 r. weszła w życie znowelizowana ustawa Prawo o Szkolnictwie Wyższym², w której w art. 34a ust. 1 ustawodawca wprowadza Zintegrowany System Informacji o Nauce i Szkolnictwie Wyższym „POL-on” jako narzędzie ministerialne:

\footnotetext{
1 A. Berezowska, I. Krzysiak, Public Relations, [dostęp: 04.05.2015], www.chodkowska.edu.pl/app_cm3/files/91462.pdf.

${ }^{2}$ „Dziennik Ustaw” 2014, poz. 1198.
} 
„Minister właściwy do spraw szkolnictwa wyższego prowadzi System Informacji o Szkolnictwie Wyższym w ramach Zintegrowanego Systemu Informacji o Nauce i Szkolnictwie Wyższym »POL-on«, zwany dalej »Systemem POLon «, obejmujący dane, o których mowa w art. 35 ust. 1 i 2 oraz ust. 3 pkt 2 i 3 oraz art. 100 ust. 3, repozytorium, o którym mowa w art. $167 \mathrm{~b}$ ust. 1, wykazy, o których mowa w art. 129a, art. 170c i art. 201a, a także wykazy, o których mowa $\mathrm{w}$ art. $31 \mathrm{a}$ ust. $1 \mathrm{i}$ art. $31 \mathrm{~b}$ ust. 1 , oraz bazę, o której mowa $\mathrm{w}$ art. $31 \mathrm{~d}$ ust. 1 Ustawy z dnia 14 marca 2003 r. o stopniach naukowych i tytule naukowym oraz o stopniach $i$ tytule $w$ zakresie sztuki, w ust. 1a precyzuje, że „Zintegrowany System Informacji o Nauce i Szkolnictwie Wyższym »POLon « jest systemem teleinformatycznym $\mathrm{w}$ rozumieniu art. 3 pkt 3 Ustawy $z$ dnia 17 lutego 2005 r. o informatyzacji działalności podmiotów realizujących zadania publiczne $e^{3}$ prowadzonym przez ministra właściwego do spraw szkolnictwa wyższego oraz ministra właściwego do spraw nauki" 4 .

Funkcjonalności systemu POL-on umożliwiają zarówno wprowadzanie danych $\mathrm{z}$ poziomu uprawnionych operatorów w jednostkach naukowych, jak również raportowanie dla organów MNiSW, GUS, CKdsSiT, rektorów szkół wyższych i dyrektorów instytutów badawczych oraz ogólnodostępne przeglądanie wybranych danych.

Kolejnym aktem prawnym zobowiązującym jednostki naukowe do wprowadzania danych do systemu POL-on jest ustawa z dnia 15 stycznia $2015 \mathrm{r}$. o zmianie ustawy o zasadach finansowania nauki oraz niektórych innych ustaw $^{5}$, która w art. 4c ust. 6 nakłada obowiązek i odpowiedzialność za poprawność i terminowość wprowadzania danych na kierowników jednostek naukowych, a także precyzuje sankcje za niewywiązanie się z tych obowiązków ${ }^{6}$ : „Jednostki naukowe, które posiadają kategorię naukową i ubiegają się o środki finansowe na zadania, o których mowa w art. 18 ust. 1, są obowiązane do wprowadzania do Systemu oraz systematycznego aktualizowania danych i informacji, o których mowa w ust. 3 i 10. Za prawidłowość, rzetelność i terminowość danych i informacji wprowadzanych do Systemu odpowiada kierownik jednostki naukowej” i ust. 7 i 8 : „Nieprawidłowe, nierzetelne lub nieterminowe wprowadzenie danych i informacji do Systemu może skutkować wstrzymaniem finansowania do czasu usunięcia tych nieprawidłowości (...). W przypadku przekazania środków finansowych na naukę w wysokości ustalonej w oparciu o dane wprowadzone do Systemu przez jednostkę naukową, o której mowa w ust. 6, nieprawidłowo, nierzetelnie lub nieterminowo, Ministrowi przysługuje prawo do żądania zwrotu nienależnie pobranych środków finansowych.

${ }^{3}$ „Dziennik Ustaw” 2014 r., poz. 1114.

${ }^{4}$ Ustawa Prawo o Szkolnictwie Wyższym, „Dziennik Ustaw” 2014, poz. 1198, art. 34a, ust. 1, [dostęp: 04.05.2015], http://www.dziennikustaw.gov.pl/DU/2014/1198.

5 „Dziennik Ustaw” 2015, poz. 249.

${ }^{6}$ Ustawa z dnia 15 stycznia 2015 r. o zmianie ustawy o zasadach finansowania nauki oraz niektórych innych ustaw, ,, Dziennik Ustaw” 2015, poz. 249, art. 4c ust. 6. 
Zwrot tych środków następuje na zasadach określonych w przepisach ustawy z dnia 27 sierpnia 2009 r. o finansach publicznych ${ }^{7}$ ".

W art. 9: „Jednostki naukowe, o których mowa w art. 4c ust. 6 ustawy, o której mowa w art. 1, w brzmieniu nadanym niniejszą ustawą, wprowadzą do Systemu Informacji o Nauce dane i informacje, o których mowa w art. 4c ust. 3 i 10 ustawy, o której mowa w art. 1, w brzmieniu nadanym niniejszą ustawą, w terminie 3 miesięcy od dnia wejścia w życie niniejszej ustawy. Dane i informacje wprowadza się za okres od dnia 1 stycznia 2013 r."

Ustawa, po okresie vacatio legis, weszła w życie 24 maja 2015 r. Do niej został przygotowany projekt Rozporządzenia Ministra Nauki i Szkolnictwa Wyższego z załącznikami, określający zakres danych i terminy ich wprowadzania i uzupełniania ${ }^{8}$ :

1. „Informacje, o których mowa w art. 4c ust. 3 ustawy, są aktualizowane raz na kwartał według stanu na koniec każdego kwartału, w terminie do 30 dnia miesiąca następującego po danym kwartale, z zastrzeżeniem ust. 2-6 [podstawowe dane o działalności badawczo-rozwojowej jednostek naukowych i jej efektach].

2. Informacje, dotyczące nieruchomości, o których mowa w art. 4c ust. 3 pkt 12 ustawy, są aktualizowane w terminie do dnia 30 kwietnia.

3. Informacje zawarte $\mathrm{w}$ wykazie, o którym mowa $\mathrm{w}$ art. $4 \mathrm{c}$ ust. 10 ustawy, są aktualizowane $\mathrm{w}$ terminie $14 \mathrm{dni}$ od dnia zmiany tych informacji [o pracownikach jednostki naukowej].

4. Informacje, o których mowa w art. 4c ust. 3 pkt 13 ustawy, są aktualizowane według stanu na dzień 31 grudnia, w terminie do dnia 30 kwietnia następnego roku [o wyniku finansowym jednostki naukowej].

5. Informacje, o których mowa w art. 4c ust. 4 pkt 1 ustawy, są aktualizowane w terminie 14 dni od dnia ogłoszenia przez ministra wykazu czasopism, zgodnie z przepisami wydanymi na podstawie art. 44 ust. 2 ustawy [o czasopismach naukowych wraz z liczbą punktów przyznawanych za publikację w tych czasopismach].

6. Informacje, o których mowa w art. 4c ust. 4 pkt 2 ustawy, są aktualizowane raz w roku w terminie do dnia 30 kwietnia [o cytowaniach publikacji]".

W załączniku nr 1 do Rozporządzenia, w części 2 umieszczono zakres danych dotyczący: „Informacji o publikacjach w czasopismach naukowych oraz monografiach naukowych lub rozdziałach w monografiach naukowych autorstwa pracowników jednostki naukowej oraz publikacjach osób niebędących pracownikami jednostki naukowej, które afiliowały te publikacje do jednostki naukowej”.

${ }^{7}$ „Dziennik Ustaw” 2013, poz. 885, z późn. zm.

${ }^{8}$ Propozycja Rozporządzenia Ministra Nauki i Szkolnictwa Wyższego, [dostęp: 10.04.2015], http://www.bip.nauka.gov.pl/rozporzadzenia_projekty/projekt-rozporzadzenia-wsprawie-systemu-informacji-o-nauce.html. 
Wątpliwości bibliotekarzy wzbudzają żądane informacje, których dotychczas nie gromadzono w bazach o dorobku publikacyjnym pracowników: objętość publikacji w arkuszach wydawniczych, dotycząca również artykułów w czasopismach naukowych, informacje o podmiocie posiadającym majątkowe prawa autorskie do publikacji (autor/wydawca/pracodawca/inny podmiot) oraz informacje o otwartym dostępie do publikacji (open access). Uzupełnienie istniejących opisów publikacji za wymagany rozporządzeniem okres od 01.01.2013 r. o wyżej wymienione dane będzie wymagało sięgnięcia do umów zawieranych przez autorów $\mathrm{z}$ wydawcami $\mathrm{i}$ te prace będą musieli wykonać sami autorzy, co z pewnością skomplikuje i wydłuży ten proces.

Jednostki naukowe, w tym szkoły wyższe, w większości nie dysponują własnymi centralnymi bazami danych dla wymaganych przez MNiSW informacji. Posiadają i prowadzą tematyczne bazy/rejestry informacji, na przykład: bazy informacji o publikacjach naukowych pracowników ${ }^{9}$, bazy informacji o pracownikach (dane kadrowe), bazy informacji o studentach (dane dziekanatowe).

Zakres informacji, jakie MNiSW chce otrzymywać ze szkół wyższych i instytutów badawczych jest dużo bardziej obszerny, wymienia je propozycja Rozporządzenia Ministra Nauki i Szkolnictwa Wyższego oraz obszary tematyczne systemu POL-on. Oprócz podstawowych danych o jednostkach naukowych i uczelniach wyższych, ilustrujących strukturę szkolnictwa wyższego i nauki w Polsce, w systemie mają być gromadzone i aktualizowane informacje o prawach jednostek do nadawania stopni naukowych doktora i doktora habilitowanego w poszczególnych dziedzinach i dyscyplinach nauki i sztuki oraz informacje o posiadanych przez jednostki uprawnieniach do prowadzenia studiów na określonych poziomach w profilach kształcenia na określonych kierunkach. W efekcie, dla zainteresowanych kształceniem na poziomach szkół wyższych, MNiSW uruchomiło na bazie zebranych danych, Portal z informacjami o kierunkach studiów prowadzonych przez uczelnie wyższe w Polsce oraz Listę ostrzeżen ministra. Lista obejmuje wiadomości istotne dla młodzieży na etapie wyboru szkoły wyższej:

1. „Podstawowe jednostki organizacyjne, które otrzymały negatywną ocenę programową na prowadzonych kierunkach studiów, informacje o zawieszeniu i cofnięciu uprawnień uczelni do prowadzenia studiów.

2. Informacje o wygaśnięciu uprawnień uczelni do prowadzenia studiów.

3. Informacje o cofnięciu pozwolenia na utworzenie uczelni niepublicznej.

4. Informacje o wydaniu zgody na likwidację uczelni niepublicznych.

5. Uczelnie niepubliczne postawione w stan likwidacji”10.

\footnotetext{
${ }^{9} 85$ uczelni instytutów naukowych i badawczych tworzy te bazy w systemie Expertus firmy Splendor: Splendor ${ }^{\circledR}$ Systemy Informacyjne [dostęp: 03.05.2015], http://www.splendor. net.pl/s0500001.htm

${ }^{10}$ Lista ostrzeżeń ministra, [dostęp: 10.04.2015], https://polon.nauka.gov.pl/opi/aa/lista Ostrzezen?execution $=\mathrm{e} 1 \mathrm{~s} 1$.
} 
Ponadto w systemie przewidziano moduły, w których rejestrowane mają być informacje służące zarządzaniu nauką, będące jednocześnie bazami wspomagającymi sprawozdawczość sektora nauki dla pozostałych instytucji.

Dwie bazy z danymi osobowymi już istnieją i są systematycznie uzupełniane: Rejestr Pracowników Naukowych i Nauczycieli Akademickich i Ogólnopolski Wykaz Studentów. Informacje z tych baz w założeniu mają służyć zwiększeniu efektywności i poprawności wydatkowania środków publicznych przeznaczonych zarówno na finansowanie etatów pracowników naukowych i naukowo-dydaktycznych (minima kadrowe na poszczególnych kierunkach studiów, kontrola wieloetatowości), jak i pomoc materialną dla studentów (kontrola poprawności dysponowania środkami na ten cel).

Informacje o nagrodach i wyróżnieniach przyznanych instytucjom lub jej pracownikom, informacje o konferencjach naukowych, których organizatorem lub współorganizatorem była jednostka, informacje na temat patentów, zgłoszonych wynalazków, praw ochronnych i autorskich, jak również wdrożonych produktów czy wyników badań mają ilustrować aktywność naukową i osiągnięcia uczelni lub instytutu badawczego. MNiSW chce dysponować centralną bazą o nieruchomościach, infrastrukturze, laboratoriach i aparaturze w szkołach wyższych i jednostkach naukowych. Będzie to jednocześnie kontrola wydatkowania środków publicznych, $\mathrm{z}$ których pokrywane są koszty zakupu i utrzymania obiektów, laboratoriów wraz z wyposażeniem badawczym. Baza ma charakter ogólnodostępny i stanowi rodzaj oferty o zapleczu naukowobadawczym i zasobach badawczych jednostek naukowych, której celem jest przede wszystkim upowszechnienie potencjału instytucji naukowych dla zainteresowanych, zarówno w sektorze naukowym, jak i przemysłowym i jego efektywne wykorzystanie. MNiSW chce wiedzieć zarówno o realizowanych w uczelniach projektach naukowych, jak i o źródłach ich finansowania.

Ankieta jednostki jest sprawozdaniem składanym raz na 4 lata przez wszystkie jednostki ubiegające się o przyznanie dotacji na podstawową działalność statutową z budżetu państwa. Na jej podstawie wyliczana jest ocena parametryczna działalności jednostki i przyznawana jest jej właściwa kategoria oraz wysokość dotacji ze środków publicznych.

W ramach funkcjonalności raportowania systemu POL-on gromadzone są dane mające na celu usprawnienie procesu sprawozdawania działalności uczelni, poprzez zastąpienie sprawozdań składanych do GUS, MNiSW i Ministerstwa Finansów jednym standardowym sprawozdaniem.

$\mathrm{Z}$ informacji zamieszczonych na stronie systemu POL-on wynika, że $\mathrm{w}$ przyszłości będą $\mathrm{w}$ nim zbierane także informacje o znajdujących się $\mathrm{w}$ posiadaniu uczelni zbiorach bibliotecznych ${ }^{11}$. Co i w jaki sposób ustawodawca chciałby osiągnąć realizując takie założenie nie zostało sprecyzowane.

\footnotetext{
${ }^{11}$ O systemie, [dostęp: 04.05.2015], https://polon.nauka.gov.pl/system.
} 
Czy miałby to być rodzaj agregatora przeszukującego katalogi bibliotek naukowych, czy też jednego wspólnego systemu bibliotecznego z centralnym katalogiem zbiorów, okaże się prawdopodobnie w fazie realizacji.

Rodzi się zasadnicze pytanie, czy szkoły wyższe i instytuty naukowe powinny budować wewnętrzne systemy zarządzania wiedzą, z których w ustawowych terminach będą przesyłane informacje do systemu POL-on, czy raczej powinny wykorzystać system centralny i bezpośrednio do niego wprowadzać dane. Instytucje, które już dysponują systemami wewnętrznymi, mają wdrożony również system organizacyjny, zapewniający uzupełnianie danych. Tym samym dysponują wewnątrz jednostki tak zwaną referencyjną bazą danych i mogą ją wykorzystać zarówno do przekazywania danych do systemu POLon, jak i do zarządzania własną jednostką na podstawie dotychczas przyjętych kryteriów oraz promocji instytucji. Problemem jednakże jest komunikacja systemu centralnego z systemami wewnętrznymi instytucji. Tylko w przypadku kilku modułów systemu POL-on (jednostkowe dane studentów, pracowników naukowych oraz doktorantów, a także publikacje naukowe do systemu PBN) przewidziano tak zwany masowy import plików ${ }^{12}$, pozostałe muszą być wypełniane ręcznie, niezależnie od istnienia baz wewnętrznych, zwłaszcza, że MNiSW nie przewidziało również komunikacji z własnymi, dotychczas istniejącymi bazami ${ }^{13}$. W tej sytuacji, istotna dla zarządzających szkołami wyższymi i instytutami naukowymi jest odpowiedź na pytanie o możliwości organizacyjne, co najmniej podwójnego raportowania: do systemów wewnętrznych i systemu centralnego.

Dla bibliotek naukowych zasadnicza jest ich rola w uczelnianym systemie raportującym. Bibliotekarze tworzą i prowadzą lokalne bazy o publikacjach naukowych pracowników jednostek, na podstawie których przekazują zestawienia na żądanie władz uczelni, dziekanów lub pracowników naukowych. Informacje $\mathrm{z}$ tych baz mogą być przekazywane metodą importu masowego plików do modułu PBN w systemie POL-on. Z pewnością udział bibliotek w pierwszym etapie zasilenia systemu jest bezcenny, choć przy braku niezbędnych informacji, dotyczących mechanizmów importu i braku możliwości prowadzenia testów na 3 miesiące przed ustawowym terminem, jest zadaniem obarczonym ogromną odpowiedzialnością. Zakładając jednak, że efekt będzie pozytywny, pozostaje odpowiedź na pytanie, jak powinien wyglądać docelowy model bieżącego tworzenia „bibliografii instytucjonalnej” i jaką rolę w tym modelu ma pełnić w przyszłości biblioteka. Oto trzy prawdopodobne rozwiązania, jakie autorki opracowały:

\footnotetext{
${ }^{12}$ M. Michajłowicz, A. Bochenek, Instrukcja importu masowego $w$ wersji 5.0. Propozycja zmian $w$ masowym imporcie danych $w$ zwiazku z nowelizacja ustawy o finansowaniu nauki, [dostęp: 04.05.2015], https://polon.nauka.gov.pl/c/document_library/get_fileuuid= 112e65af-4fc7-4f57-93c5- d513a84a6138\&groupId=10157.

${ }^{13}$ Bazy OPI w serwisie Nauka Polska: Instytucje; Ludzie nauki; Prace badawcze (system SYNABA); Konferencje naukowe, targi i wystawy; Projekty archiwalne, [dostęp: 04.05.2015], http://www.opi.org.pl/Nauka-Polska.html.
} 
1. Model 1, w którym bibliografię instytucjonalną tworzy się lokalnie, w oparciu o dotychczas wykorzystywane systemy komercyjne lub własne. Opisy do baz wprowadzają bibliotekarze. Import masowy plików do syte$\mathrm{mu}$ POL-on jest przeprowadzany zgodnie $\mathrm{z}$ terminarzem określonym w Rozporządzeniu MNiSW. Należy pamiętać, że w tym modelu odpowiedzialność za wypełnienie ustawowego obowiązku: za zbieranie informacji od autorów publikacji, ich kompletność, poprawność, terminowość i transfer danych, a w konsekwencji za skutki operacji, spoczywa przede wszystkim na bibliotekach. Nie ma pewności, że kierownicy jednostek naukowych wyrażą zgodę na takie rozwiązanie.

2. Model 2, zakładający wykorzystanie uczelnianych systemów zarządzania wiedzą (CRIS). Wprowadzanie danych w systemach z reguły jest rozproszone, czynności wprowadzania opisów są realizowane w jednostkach podstawowych przez osoby wskazane i uprawnione przez kierownika jednostki. Na bibliotekarzach może spoczywać zadanie kontroli poprawności wprowadzonych opisów. Otwartym pozostaje pytanie: kto w takim modelu odpowiada za import danych do systemu POL-on: instytucjonalne centra komputerowe, czy administratorzy uczelnianych systemów zarządzania wiedzą, administratorzy w jednostkach podstawowych czy też może bibliotekarze?

3. Model 3, zakładający, że dane o dorobku publikacyjnym wprowadza się bezpośrednio do modułu PBN w systemie POL-on. Tym samym referencyjna baza danych $\mathrm{w}$ zakresie dorobku publikacyjnego pracowników będzie ulokowana poza instytucją, w systemie centralnym. Za poprawne lub błędne wprowadzenie danych do systemu centralnego oraz terminowość wykonania czynności odpowiada kierownik jednostki naukowej, czyli osoba ustawowo zobligowana do ich wykonania. Kierownik jednostki ma możliwość zorganizowania właściwego, efektywnego procesu wprowadzania danych do systemu POL-on, nakładając dodatkowe obowiązki wybranym pracownikom lub zatrudniając do wykonania zadania nowych pracowników. Kierownik jednostki dysponuje w tym celu właściwymi narzędziami motywującymi. Biblioteka może zostać włączona w realizację zadania wprowadzania danych o publikacjach pracowników poprzez organizację szkoleń i wsparcia merytorycznego dla operatorów w jednostkach.

Właściwy model zasilania systemu centralnego będzie z pewnością określony wewnętrznymi zarządzeniami, odrębnymi dla każdej instytucji. Różne też mogą być obowiązki nałożone na biblioteki.

Odrębną kwestią jest rola bibliotek w tworzeniu i funkcjonowaniu repozytoriów instytucjonalnych, zawierających nie tylko dorobek naukowy pracowników ich macierzystych uczelni w postaci artykułów, rozdziałów z książek czy monografii, ale także rozprawy doktorskie i dokumenty nieopublikowane. Większość istniejących repozytoriów została zainicjowana przez biblioteki naukowe, stąd posiadają one największe doświadczenie i umiejętności 
organizacyjne w realizacji tego rodzaju projektów. Należy pamiętać, że system centralny POL-on ma opcję dla autorów, polegającą na dobrowolnym deponowaniu własnych publikacji. W zamyśle pomysłodawców jest, być może, utworzenie również centralnego ogólnopolskiego repozytorium publikacji naukowych. Dziś jest to oferta dla tych instytucji, które nie mają własnych repozytoriów. Również propagowanie idei open access odbywa się z aktywnym udziałem bibliotekarzy. Nie ma wprawdzie w chwili obecnej obligacji ustawowej do budowy repozytoriów w szkołach wyższych, ale wiele uczelni już dostrzega konieczność ich instytucjonalnego posiadania. Często ten element działalności jest dodatkowo punktowany i tym samym może znacząco wpływać na całościową ocenę oraz lokatę szkoły wyższej w rankingach zarówno krajowych, jak i międzynarodowych. Najbardziej reprezentatywnym tego przykładem jest Webometryczny Ranking Uczelni Świata: http://www.webo metrics.info oraz webometryczny ranking prowadzonych przez nie repozytoriów: http://repositories.webometrics.info.

Internet nieodwracalnie zmienił komunikację w środowisku naukowym. Środki przekazu i wymiany informacji, w postaci stron WWW, poczty elektronicznej, forów dyskusyjnych, komunikatorów internetowych czy telekonferencji, są dziś obecne w warsztacie przeważającej większości badaczy. Coraz częściej znajdują tam też zastosowanie narzędzia i serwisy społecznościowe, takie jak: Twitter, Facebook, Google Scholar, Mendeley oraz blogi naukowe. Korzystają z nich specjaliści różnych dziedzin, pragnąc dzielić się otrzymanymi wynikami i stawianymi tezami, jak najszybciej, z podobnymi im naukowcami z powołania. Są też i tacy, którzy za pomocą sieci internetowej, rozwijają wyłącznie naukowy narcyzm. Należy jednak podkreślić, że nie zawsze rezultaty badań mogą i muszą być powszechnie czy społecznościowo dostępne. W szczególności będzie dotyczyło to wyników, których opracowanie może stanowić know-how, podstawę komercjalizacji badań lub przedmiot postępowania patentowego. Mimo to, wszyscy naukowcy, mniej lub bardziej świadomie, uczestniczą w publish-or-perish culture ${ }^{14}$.

Wymienione wcześniej rankingi webometryczne są tworzone na podstawie web-wskaźników wypracowanych przez grupę badawczą Cybermetrics Lab, działającą przy IPP-CCHS ${ }^{15}$, która podlega hiszpańskiej Najwyższej Radzie ds. Badań Naukowych ${ }^{16}$, z siedzibą w Madrycie. Kierownikiem zespołu, prowadzącego badania w kontekście komunikacji naukowej w sieci, czyli między innymi obecności naukowców i widoczności ich dorobku w cyberprzestrzeni, jest Isidro Francisco Aguillo, autor licznych prac naukowych z tej

${ }^{14}$ Publish-or-Perish Culture Promotes Scientific Narcissism, [dostęp: 04.04.2015], http:// scholarlykitchen.sspnet.org/2012/05/07/publish-or-perish-culture-promotes-scientific-narcissism.

${ }^{15}$ Hiszp. Instituto de Bienes y Políticas Públicas (IPP) del Centro de Ciencias Sociales y Humanas (CCHS).

${ }^{16}$ Hiszp. Consejo Superior de Investigaciones Científicas (CSIC). 
dziedziny od prawie już 20 lat $^{17}$. Jest on również jednym z założycieli oraz głównym redaktorem otwartego czasopisma elektronicznego: „Cybermetrics. International Journal of Scientometrics, Informetrics and Bibliometrics"18, ukazującego się od 1997 r., które jako jedno z pierwszych podjęło problematykę dostosowania metodologii i wykorzystania narzędzi badawczych naukometrii, informetrii i bibliometrii $\mathrm{w}$ nowo rozwijającej się dziedzinie, webometrii, (w tytule czasopisma użyto równoznacznego terminu - cybermetria ${ }^{19}$ ). Głównym przedmiotem badań webometrii jest WWW, postrzegana jako zbiór obiektów cyfrowych $\mathrm{i}$ innych elektronicznych źródeł informacji, powiązanych ze sobą linkami (odnośnikami), o różnych i skomplikowanych typach zależności. Do analiz systemu hipertekstowego, wykorzystywane są liczne metody matematyczne i statystyczne. Wypracowana została także pewna analogia między cytowaniem dokumentów drukowanych a linkowaniem obiektów cyfrowych w sieci. Niemniej jednak te powiązania nie mogą być ze sobą jednoznacznie utożsamiane. Środowisko WWW charakteryzuje się ogromną dynamiką zmian w czasie - nieograniczonym przyrostem danych, nietrwałością zawartości stron, różnorodnością strukturalną i hierarchiczną dokumentów podlegających badaniom, dużym stopniem rozproszenia treści, a co więcej, liczba połączeń i cytowań, określana tutaj mianem sytowań (sitations), może zmieniać się znacząco $^{20}$. Webometria opisuje w sposób ilościowy proces komunikacji naukowej, do tego celu korzysta z zasobów dostępnych publicznie w sieci, także z tej, określanej mianem niewidocznej lub ukrytej. Analizowane są też obiekty cyfrowe znajdujące się w uczelnianych bazach danych, repozytoriach oraz otwarte czasopisma elektroniczne ${ }^{21}$.

Ranking Repozytoriów Uczelni Świata nie jest najstarszym rozwijanym przez Cybermetrics Lab, pierwszym był Webometryczny Ranking Uniwersytetów Świata, który istnieje już od 2004 r. Później natomiast, powstały rankingi: ośrodków badawczych - od 2006 r., repozytoriów - od 2008 r., szpitali - od 2008 r. oraz szkół biznesu i MBA - od 2008 r. do 2012 r. Rankingi aktualizowane są dwa razy w roku. Na podstawie danych zebranych w pierwszych tygodniach stycznia i lipca, dokonywana jest ich analiza webometryczna. Uzyskane wyniki, wizualizowane są w postaci rankingów, nie wcześniej niż dwudziestego ósmego dnia tych miesięcy. Do edycji styczniowej 2015 r., analizie poddano 25000 uczelni wyższych z całego świata. Głównym celem

${ }^{17}$ Zob. profil naukowy: Directorio de personal, [dostęp: 04.04.2015], http:// www.cchs.csic.es/es/personal/Isidro.aguillo.

${ }^{18}$ Cybermetrics. International Journal of Scientometrics, Informetrics and Bibliometrics, [dostęp: 04.04.2015], http://cybermetrics.cindoc.csic.es/news.html.

${ }^{19}$ M. Skalska-Zlat, Cybermetria, netometria, webometria - nowe pojęcia i zadania informetrii, [w:] Przestrzeń informacji i komunikacji społecznej, Kraków 2004, s. 159-168.

${ }^{20} \mathrm{P}$. Ingwersen, The calculation of Web Impact Factor, "Journal of Documentation", 1998, Vol. 54, No. 2, s. 236-243

${ }^{21}$ I.F. Aguillo [et al.], Indicators for a webometric ranking of open access repositories, "Scientometrics", 2010, 82 (3), s. 477-486. 
rankingu uczelni jest: ,,[...] to promote Web publication. Supporting Open Access initiatives, electronic access to scientific publications and to other academic material as primary targets. If the web performance of an institution is below the expected position according to their academic excellence, university authorities should reconsider their web policy, promoting substantial increases of the volume and quality of their electronic publications"22.

$\mathrm{Na}$ pozycję rankingową danej uczelni wpływają dwie grupy czynników, jest to tak zwana widoczność i aktywność w sieci (udziały w ocenie po 50\%). Widoczność mierzona jest tak zwanym wskaźnikiem wpływu (impact) - jest to liczba odesłań - przychodzących przekierowań (external inlinks) ze stron innych instytucji lub osób trzecich, do wartościowych informacyjnie treści znajdujących się na stronie danej uczelni. Wielkość tej liczby świadczy o prestiżu i rozpoznawalności uczelni przez użytkowników sieci. Dane do wyznaczenia tego wskaźnika zbierane są za pomocą narzędzi: Majestic SEO i ahrefs. Na aktywność uczelni, składają się następujące trzy wskaźniki: obecność (udział 1/3, presence), otwartość (udział 1/3, openness) i doskonałość (udział 1/3, excellence). Obecność, to całkowita liczba stron i podstron w domenie uczelnianej, zaindeksowanych przez wyszukiwarkę Google - dotyczy to zarówno stron statycznych i dynamicznych, ale także plików w formatach .pdf, .doc, .docx, .ppt. Wysoką wartość wskaźnika otwartości zapewniają otwarte repozytoria instytucjonalne ${ }^{23}$, których zasoby są indeksowane, przeszukiwane i prezentowane w wynikach Google Scholar. Miarą doskonałości jest natomiast liczba

Tabela 1

Webometryczny Ranking Uczelni Świata - Europa - Polska - Łódź

\begin{tabular}{|c|c|c|c|c|c|c|}
\hline $\begin{array}{c}\text { Ran- } \\
\text { king }\end{array}$ & $\begin{array}{c}\text { World } \\
\text { Rank }\end{array}$ & Uczelnia & $\begin{array}{c}\text { Presence } \\
\text { Rank }\end{array}$ & $\begin{array}{c}\text { Impact } \\
\text { Rank }\end{array}$ & $\begin{array}{c}\text { Open- } \\
\text { ness } \\
\text { Rank }\end{array}$ & $\begin{array}{c}\text { Excel- } \\
\text { lence } \\
\text { Rank }\end{array}$ \\
\hline 11 & 842 & Uniwersytet Łódzki & 549 & 1624 & 506 & 1257 \\
\hline 13 & 1182 & Politechnika Łódzka & 1155 & 2071 & 1603 & 1301 \\
\hline 52 & 2943 & $\begin{array}{c}\text { Uniwersytet Medyczny } \\
\text { w Łodzi }\end{array}$ & 8227 & 6090 & 7219 & 937 \\
\hline 82 & 5639 & $\begin{array}{c}\text { Akademia Humanist. } \\
\text {-Ekonom. w Łodzi }\end{array}$ & 6476 & 6590 & 4004 & 5414 \\
\hline 86 & 5875 & $\begin{array}{c}\text { Wyższa Szkoła Informa- } \\
\text { tyki w Łodzi }\end{array}$ & 5803 & 4298 & 9143 & 5414 \\
\hline
\end{tabular}

Źródło: Webometryczny Ranking Uczelni Świata - Europa - Polska, [dostęp: 10.04.2015], http://www.webometrics.info/en/europe/poland.

${ }^{22}$ Methodology, [dostęp: 10.04.2015], http://www.webometrics.info/en/Objetives.

${ }^{23}$ O. Pekka, Does Openness and Open Access Policy Relate to the Success of Universities?, [dostęp 10.04.2015], http://elpub.scix.net/cgi-bin/works/Show?_id=110_elpub2013. 
publikacji, wydanych w czasopismach o znaczeniu międzynarodowym, zwykle o wysokim współczynniku IF, w ilości odpowiadającej 10\% najczęściej cytowanych publikacji naukowych. Dostawcą danych do tej analizy jest Scimago group: http://www.scimagoir.com.

Z Polski do bieżącego rankingu zakwalifikowało się 430 uczelni. Spośród łódzkich, najwyższą lokatę uzyskał Uniwersytet Łódzki, jednocześnie znalazł się on w przedziale do tysiąca najlepszych uczelni świata (tab. 1). Wymienione poniżej, inne łódzkie uczelnie, należą do grupy 100 najlepszych w kraju.

W głównym Rankingu Repozytoriów Uczelni Świata ${ }^{24}$, obejmującym repozytoria dziedzinowe i instytucjonalne, z Europy zarejestrowanych zostało 875 repozytoriów, w tym z Polski -27 . Pierwsze, chlubne miejsce, zajmuje Repozytorium Uniwersytetu im. Adama Mickiewicza w Poznaniu - AMUR: http://repozytorium.amu.edu.pl. W ogólnoświatowym zestawieniu zostało ono sklasyfikowane na 155-tej pozycji, natomiast wszyscy pozostali uczestnicy polskiego rankingu, znaleźli się poniżej 550-tego miejsca. Należy zauważyć, że w rankingu, obok wzorcowych repozytoriów instytucjonalnych, zarejestrowane są też biblioteki cyfrowe - instytucjonalne, regionalne lub dziedzinowe oraz archiwum między innymi dokumentów życia społecznego. Autorzy rankingu podkreślają znaczenie sieci, bibliotek cyfrowych i repozytoriów w kontekście komunikacji naukowej: ,,[... The Web, digital libraries and repositories are changing the way scientific knowledge is distributed and accessed, providing new opportunities for a more exhaustive and balanced coverage of the scholar literature" 25 .

Dodatkowo osobno wydzielony został ranking wyłącznie samych repozytoriów instytucjonalnych ${ }^{26}$, który powstaje na podstawie nieco innej analizy danych surowych, wykorzystanych też w rankingu głównym. Trzecim rankingiem uzupełniającym jest ranking tak zwanych portali ${ }^{27}$, które nie mogą zostać zaklasyfikowane do żadnego $\mathrm{z}$ powyższych rankingów repozytoriów, w tej grupie znajduje się między innymi: Academia.edu, ResearchGate, Repozytorium Cyfrowe Instytutów Naukowych RCIN, Repozytorium CeON i CYBRA - Łódzka Regionalna Biblioteka Cyfrowa. Głównym celem rankingu repozytoriów jest: ,[...] to promote Open Access initiatives (OAI) supporting the use of repositories for scientific evaluation purposes" 28 .

\footnotetext{
${ }^{24}$ Webometryczny Ranking Repozytoriów Świata - Europa - Polska, [dostęp: 10.04.2015], $\mathrm{http} / / /$ repositories.webometrics.info/en/Europe/Poland.

${ }^{25}$ I.F. Aguillo [et al.], op. cit., s. 477-486. top_Inst.

${ }^{26}$ Top institutionals, [dostęp: 10.04.2015], http://repositories.webometrics.info/en/

${ }^{27}$ Top portals, [dostęp: 10.04.2015], http://repositories.webometrics.info/en/top_portals.

${ }^{28}$ I.F. Aguillo [et. al.], op. cit., s. $477-486$.
} 
Podobnie jak w przypadku rankingu uczelni, badana jest przejrzystość linkowania (visibility) oraz mierzona liczba przekierowań z innych serwisów (backlinks) za pomocą narzędzi MajesticSEO i ahrefs. Oceniana jest także, obecność zasobów repozytoryjnych w sieci, na podstawie danych zebranych przez komercyjne wyszukiwarki typu Google (size). Proporcje tych dwóch grup wskaźników przyjęto za 1:1. Oprócz powyższych, analizowane są wystąpienia plików w formatach .pdf, .doc, .docx, .ppt, .pptx, .ps, .eps. Ostatnim parametrem jest scholar, czyli publikacje z ostatnich pięciu lat (bez bieżącego) i ich wartość naukowa, zaindeksowane i widoczne w Google Scholar.

Tylko repozytoria (według nazewnictwa stosowanego w rankingu) o samodzielnej nazwie domenowej lub subdomenowej mogą znaleźć się w rankingu. Trzy, spośród 27 znajdujących się w rankingu instytucji, posiada zarejestrowaną bibliotekę cyfrową równolegle $\mathrm{z}$ repozytorium instytucjonalnym. Co więcej $\mathrm{w}$ rankingu znalazły się też uczelnie, które posiadają repozytoria, a w rankingu jest prezentowana wyłącznie biblioteka cyfrowa. Kolejne kryterium, czyli szczegółowy zapis nazwy domenowej według schematu: repository.university.country, spełnia tylko 5 polskich repozytoriów. Pozostałe zawierają $\mathrm{w}$ nazwie na przykład: rodzaj używanego oprogramowania (dspace, dlibra-delibra, eprints), skrót bg oznaczający bibliotekę główną - organizatora repozytorium lub skrót własny, przez siebie ustalony.

$\mathrm{Z}$ założenia zawartość repozytoriów powinny stanowić głównie dokumenty naukowe pochodzące $\mathrm{z}$ danej jednostki uczelnianej. Blisko $60 \%$ spełnia to kryterium. Pozostałe repozytoria oprócz publikacji naukowych udostępniają także zabytki dziedzictwa kulturowego, które stanowią większość takich zasobów. Przedmiotem dalszej analizy będzie tylko 5 wcześniej wyróżnionych repozytoriów. Wszystkie repozytoria prezentują swoje zasoby w podziale na jednostki właściwe ich uczelniom. Dodatkowo wydzielonymi kolekcjami, mogą być:

- archiwum prac dyplomowych (na przykład „Archiwum Prac Dyplomowych Krakowskiej Akademii im. Andrzeja Frycza Modrzewskiego ${ }^{29}$ "');

- $\quad$ archiwum doktoratów (na przykład Doktoraty 2010-2015 / dostęp ograniczony, możliwy z komputerów w Bibliotece Uniwersyteckiej Uniwersytetu im. Adama Mickiewicza w Poznaniu ${ }^{30}$ ).

Dostęp do tak wydzielonych zasobów jest niestety zastrzeżony. Blisko 11000 obiektów naukowych zawiera łącznie repozytorium AMUR, następnie nieco ponad 3500 - repozytorium Uniwersytetu w Białymstoku, 2500 - repozytorium Uniwersytetu Mikołaja Kopernika oraz porównywalnie - od 1300

${ }^{29}$ eRIKA - Repozytorium Instytucjonalne Krakowskiej Akademii im. Andrzeja Frycza Modrzewskiego - zbiór „Archiwum Prac Dyplomowych KAAFM”, [dostęp: 10.04.2015], https:// repozytorium.ka.edu.p1/handle/11315/860.

${ }^{30}$ Repozytorium Uniwersytetu im. Adama Mickiewicza - kolekcja ,,Doktoraty 2010-2015/ dostęp ograniczony, możliwy z komputerów w Bibliotece Uniwersyteckiej/”, [dostęp: 10.04.2015], https://repozytorium.amu.edu.pl/jspui/handle/10593/104. 
do 1600, repozytorium Krakowskiej Akademii im. Andrzeja Frycza Modrzewskiego i Uniwersytetu Kazimierza Wielkiego w Bydgoszczy ${ }^{31}$.

Przeważającą część tych zasobów stanowią artykuły z czasopism wydawanych przez właściwe uczelnie i są one dostępne w open access, na licencjach CC lub z embargiem, podobnie jak większość innych dokumentów naukowych deponowanych przez samych naukowców. W bieżącym roku będą brane pod uwagę tylko repozytoria z zasobami otwartymi w ilości minimum $90 \%$. Dodatkowo twórcy rankingu zwrócą uwagę na nazewnictwo deponowanych plików sugerowany schemat to TytułAutorRokWydania ${ }^{32}$.

Kolejnym rankingiem, nowo rozwijanym przez Cybermetrics Lab, jest Webometryczny Ranking Pracowników Uczelni Świata, który znajduje się jeszcze w fazie testów i stanowi na razie tylko propozycję. W części jest on efektem analizy wyników, uzyskanych przez Cybermetrics Lab podczas badania, przeprowadzonego na grupie najczęściej cytowanych naukowców, dotyczącego ich obecności w sieci. Metodologię wyboru tej grupy określono w ramach wcześniejszych badań ${ }^{33}$ - do tego celu wykorzystana została między innymi baza danych ISIHiglyCited.com ${ }^{34}$.

Do analizy wybrano dwudziestu dwóch najczęściej cytowanych naukowców w przedziale lat 1981-2008, pracowników europejskich instytucji badawczych, przedstawicieli pięciu ogólnych dziedzin: nauk inżynierskich, fizycznych, społecznych, o życiu i o zdrowiu. Z Polski, w tym gronie znalazły się trzy osoby. Dla tej próby obiektów zbadano dwa rodzaje, wcześniej zidentyfikowanych, obecności w sieci:

- $\quad$ instytucjonalną (w postaci osobistych stron WWW lub należących do grup na przykład laboratoryjnych, tworzone w obrębie domenowych stron WWW instytucji badawczych lub uczelni, przez samych naukowców albo dla nich);

- $\quad$ społecznościową (jako rezultat korzystania z profili Google Scholar, Microsoft Academic Search, menedżera organizacji bibliografii i dzielenia się publikacjami naukowymi Mendeley, serwisów społecznościowych typu LinkedIn, Academia.edu i zawartości serwisu SlideShare).

Celem sprawdzenia, czy najczęściej cytowani naukowcy posiadają osobiste strony www, wykonano ręczne przeszukanie Internetu za pomocą wyszukiwarki Google. W tym przypadku przyjętymi wskaźnikami były linki odsyłające do takich stron. Dla społecznościowej obecności w sieci przeprowadzono

\footnotetext{
${ }^{31}$ Zestawienie polskich bibliotek cyfrowych, [dostęp: 10.04.2015], http://fbc.pionier.net.p1/ owoc/list-libs.

${ }^{32}$ Important Info for Future Editions (Updated 11 Sept14), [dostęp: 10.03.2015], http:// repositories.webometrics.info/en/node/26.

${ }^{33}$ A. Mas-Bleda [et al.], European highly cited scientists' presence in the social Web, [in:] Proceeding of 14th International Society of Scientometrics and Informetrics Conference, Vienna-Austria, 2013, s. 1966-1967.

${ }^{34}$ Highly Cited Researchers, Thomson Reuters, [dostęp: 10.04.2015], http://research analytics.thomsonreuters.com/highlycited.
} 
podobną analizę, z tym że wykorzystano tu analizę automatyczną za pomocą narzędzia Webometric Analyst 2.0: http://lexiurl.wlv.ac.uk i dopiero wtedy dokonano ręcznej analizy i selekcji wyników. Dodatkowo za wskaźniki obecności w sieci zostały również użyte liczby: czytających, odwiedzających, śledzących, wyświetleń profili i treści, polubień i udostępnień ${ }^{35}$.

Autorzy powyższych badań zastrzegają, że są to badania pilotażowe i wymagają doboru pomocniczych narzędzi analitycznych.

Próbna lista rankingowa Top 2000 najczęściej cytowanych naukowców $\mathrm{z}$ danego kraju, utworzona została na podstawie analizy publicznie dostępnych profili Google Scholar Citations (GSC). Mogą się na niej również znaleźć byli doktoranci oraz pracownicy naukowi, którzy nie są już czynni zawodowo, ale wcześniej afiliowali swoje publikacje. Dane zostały zebrane w trzecim tygodniu stycznia 2015 r. Najwyżej w rankingu znajdują się osoby z największym indeksem Hirscha, drugim wskaźnikiem jest natomiast najwyższa liczba cytowań, wyliczana według algorytmu używanego przez Google Scholar Citations.

$\mathrm{Z}$ dwóch tysięcy naukowców, znajdujących się na polskiej liście rankingowej $^{36}$, osiemdziesięciu naukowców pochodzi $\mathrm{z}$ następujących łódzkich uczelni: Politechniki Łódzkiej (35; 44\%), Uniwersytetu Łódzkiego (36; 45\%), Uniwersytetu Medycznego w Lodzi $(8 ; 10 \%)$ i Akademii HumanistycznoEkonomicznej w Łodzi $(1 ; 1 \%)$. Czterech pracowników Uniwersytetu Łódzkiego afiliowało swoje prace równocześnie przy UNESCO, National Bank of Poland oraz National Cancer Institute.

W pierwszej dziesiątce polskiego rankingu najczęściej cytowanych naukowców według GSC, nie znalazł się żaden z naukowców łódzkich uczelni. Niemniej jednak Marek L. Kowalski z Uniwersytetu Medycznego w Lodzi, zajął bardzo bliską jedenastą pozycję (h-indeks 48; liczba cytowań 14 365). Inaczej jest w przypadku pierwszej setki pozycji omawianego rankingu, $w$ tym zakresie wystąpiło już sześciu łódzkich badaczy: 4 osoby z Uniwersytetu Medycznego w Łodzi oraz 2 z Politechniki Łódzkiej (tab. 2). Zdecydowanie więcej reprezentantów łódzkich uczelni znalazło się w zakresie 1 do 1000 miejsc są to już 34 osoby, w tym większość stanowią pracownicy Politechniki Łódzkiej.

Pracownicy naukowi często jednak nie są świadomi tego, że powinni aktualizować i weryfikować swoje profile z publikacjami, że używają różnych skrótów swojego imienia/on, nazwisk/a czy afiliacji, co zdecydowanie utrudnia ich jednoznaczną identyfikację, nawet w przypadku zawężenia do dziedziny, będącej przedmiotem ich zainteresowania. Przykładem na to może być publikacja, wymieniona w poniższej tabeli, wydana rzekomo w 1976 r., która okazała się preprintem z 2012 r. Stąd część danych GSC może zawierać istotne błędy, a także być znacząco zawyżona (tab. 2).

${ }^{35}$ I.F. Aguillo [et al.], Do highly cited researchers successfully use the social web?, "Scientometrics", 2014, s. 337-356, [DOI 10.1007/s11192-014-1345-0].

${ }^{36}$ Ranking of scientists in Polish Institutions according to their Google Scholar Citations public profiles, [dostęp: 10.05.2015], http://www.webometrics.info/en/node/98. 
Webometryczny Ranking Naukowców Świata - Europa - Polska - Łódź

\begin{tabular}{|c|c|c|c|c|c|c|c|c|}
\hline Lp. & $\begin{array}{c}\text { Top } \\
2000 \\
\text { Polska }\end{array}$ & $\underset{\text { i nazwisk }}{\text { Imię }}$ & Afiliacja & $\begin{array}{l}\text { indeks } \\
\text { Hirscha }\end{array}$ & $\begin{array}{c}1 . \\
\text { cytowań }\end{array}$ & $\begin{array}{c}1 . \\
\text { publikacji } \\
\text { w profilu }\end{array}$ & $\begin{array}{c}\text { Najwcześniej } \\
\text { opublikowana } \\
\text { pozycja }\end{array}$ & $\begin{array}{c}\text { Najczęściej } \\
\text { cytowana } \\
\text { pozycja vs } \\
\text { rok wydania } \\
\end{array}$ \\
\hline 1 & 11 & $\begin{array}{l}\text { Marek L } \\
\text { Kowalski }\end{array}$ & $\begin{array}{c}\text { Medical University } \\
\text { of Lodz }\end{array}$ & 48 & 14365 & 501 & 1976 & $2001(5819)$ \\
\hline 2 & 34 & $\begin{array}{l}\text { Tomasz } \\
\text { Kapitaniak }\end{array}$ & $\begin{array}{c}\text { Lodz University of } \\
\text { Technology }\end{array}$ & 37 & 4711 & 338 & 1985 & $1996(329)$ \\
\hline 3 & 55 & $\begin{array}{l}\text { Jan } \\
\text { Awrejcewicz }\end{array}$ & $\begin{array}{l}\text { Lodz University of } \\
\text { Technology }\end{array}$ & 32 & 4712 & 939 & 1983 & $2012(355)$ \\
\hline 4 & 59 & Maciej Banach & $\begin{array}{c}\text { Medical University } \\
\text { of Lodz }\end{array}$ & 32 & 4058 & 489 & 1999 & $2009(151)$ \\
\hline 5 & 78 & Jacek Rysz & $\begin{array}{c}\text { Medical University } \\
\text { of Lodz }\end{array}$ & 30 & 2864 & 310 & 1995 & $2012(94)$ \\
\hline 6 & 88 & $\begin{array}{l}\text { Jaroslaw D } \\
\text { Kasprzak }\end{array}$ & $\begin{array}{c}\text { Medical University } \\
\text { of Lodz }\end{array}$ & 28 & 5028 & 713 & 1996 & 2007 (1898) \\
\hline
\end{tabular}

Źródło: Ranking of scientists in Polish Institutions according to their Google Scholar Citations public profiles, [dostęp: 10.05.2015], http://www.webometrics.info/en/node/98.

\section{Podsumowanie}

Sytuacja $\mathrm{w}$ polskich jednostkach naukowych $\mathrm{w}$ zakresie gromadzenia danych o prowadzonych badaniach, realizowanych projektach naukowych, patentach, wdrożeniach czy dorobku publikacyjnym pracowników jest dość skomplikowana. Obserwuje się, że niektóre z nich, w tym uczelnie, wdrażają kompleksowe systemy zarządzania nauką (Current Research Information System) w oparciu o własne lub komercyjne narzędzia informatyczne. Repozytoria publikacji oraz bazy opisów publikacji stają się wtedy jednym $\mathrm{z}$ wielu elementów złożonego portalu informacyjnego o danej uczelni, który w wyniku sprzężenia z bazami, na przykład kadrową, studentów i doktorantów, prowadzonych projektów badawczych przez jednostki, bibliograficzną, czy bazą wdrożeń i patentów, pozwala na wizualizację licznych statystyk na różne sposoby.

CRIS są zatem istotnym narzędziem wspierającym promocję uczelni oraz obrazującym na przykład dynamikę aktywności naukowej uczelni. Front-end CRIS zapewnia użytkownikom Internetu przejrzystość i dostęp do wyników badań naukowych sfinansowanych ze źródeł publicznych, natomiast back-end jest istotny dla kadry zarządzającej uczelnią, jako źródło danych decyzyjnych i narzędzie ewaluacji jednostek badawczych. Jednocześnie istnieje centralny system POL-on, który musi być uzupełniany, a jego utrzymanie nie generuje kosztów po stronie uczelni. Z założenia nie wypełnia zadania kompleksowej informacji o jednostce naukowej w rozumieniu zasad public relations. Rektorzy i dyrektorzy instytutów naukowych muszą podjąć decyzję o wyborze właściwej, dla własnych instytucji ścieżki działania: budowa instytucjonalnego systemu CRIS czy też poprzestanie na wprowadzaniu danych do systemu centralnego. Wydaje się, że posiadanie instytucjonalnego CRIS zwiększa 
widoczność, zapewnia indywidualizm i promocję jednostki naukowej, a przede wszystkim zapewnia rektorom i dyrektorom narzędzie do sprawnego zarządzania jednostką. Wprawdzie organizacja wprowadzania danych do dwóch systemów jest zadaniem niezwykle skomplikowanym, przy braku w chwili obecnej sprawnej komunikacji pomiędzy systemami, jednak w efekcie może przynieść w przyszłości więcej korzyści, zwłaszcza że Laboratorium webometryczne Cybermetrics rozważa tworzenie nowego rankingu, tym razem systemów zarządzania wiedzą CRIS. Jakiekolwiek decyzje zostaną podjęte na poziomie każdej $\mathrm{z}$ jednostek naukowych, pewne jest, że biblioteki w większym lub mniejszym zakresie będą zaangażowane $\mathrm{w}$ te procesy. $\mathrm{W}$ zależności od stopnia zaangażowania, różna będzie również odpowiedzialność bibliotek za efekty ich działań.

\section{Bibliografia}

Aguillo, I.F. [et. al.], Indicators for a webometric ranking of open access repositories, "Scientometrics" 2010, 82 (3), s. 477-486.

Aguillo, I.F. [et al.], Do highly cited researchers successfully use the social web?, "Scientometrics" 2014, s. 337-356, [DOI 10.1007/s11192-014-1345-0].

Berezowska A., Krzysiak I., Public Relations, Wyższa Szkoła Zarządzania i Prawa im. Heleny Chodkowskiej w Warszawie 2012, [dostęp: 10.05.2015], www.chodkowska.edu.pl/ app_cm3/files/91462.pdf.

Important Info for Future Editions (Updated 11 Sept14), [dostęp: 10.03.2015], http:// repositories.webometrics.info/en/node/26.

Ingwersen, P., The calculation of Web Impact Factor, "Journal of Documentation", 1998, Vol. 54 , No. 2, s. 236-243.

Mas-Bleda, A. [et al.], European highly cited scientists' presence in the social Web, [in:] Proceeding of 14th International Society of Scientometrics and Informetrics Conference, Vienna-Austria 2013, s. 1966-1967.

Methodology, [dostęp: 10.04.2015], http://www.webometrics.info/en/Objetives.

Ośrodek Przetwarzania Informacji - Państwowy Instytut Badawczy. Bazy Danych, [dostęp: 10.04.2015], http://www.opi.org.pl/Nauka-Polska.html.

Michajłowicz M., Bochenek A., Instrukcja importu masowego w wersji 5.0. Propozycja zmian $w$ masowym imporcie danych $w$ zwiazku z nowelizacja ustawy o finansowaniu nauki 2015, [dostęp: 25.04.2015], https://polon.nauka.gov.pl/c/document_library/get_fileuuid $=112 \mathrm{e} 65 \mathrm{af}-4 \mathrm{fc} 7-4 \mathrm{f} 57-93 \mathrm{c} 5 \mathrm{-d} 513 \mathrm{a}$ 84a6138\& groupId $=10157$.

Pekka, O., Does Openness and Open Access Policy Relate to the Success of Universities?, [dostęp 10.04.2015], http://elpub.scix.net/cgi-bin/works/Show?_id=110_elpub2013.

POL-on. Zintegrowany System Informacji o Nauce i Szkolnictwie Wyższym, [dostęp: 10.04.2015], https://polon.nauka.gov.pl/glowna.

Propozycja Rozporzadzenia Ministra Nauki i Szkolnictwa Wyższego w sprawie Systemu Informacji o Nauce z załacznikami i komentarzem, [dostęp: 10.04.2015], http://www.bip.nau ka.gov.pl/rozporzadzenia_projekty/projekt-rozporzadzenia-w-sprawie-systemu-informacjio-nauce.html.

Ranking of scientists in Polish Institutions according to their Google Scholar Citations public profiles, [dostęp: 10.05.2015], http://www.webometrics.info/en/node/98.

Ustawa Prawo o Szkolnictwie Wyżzym, „Dziennik Ustaw” 2014, poz. 1114.

Ustawa z dnia 15 stycznia 2015 r. o zmianie ustawy o zasadach finansowania nauki oraz niektórych innych ustaw, „Dziennik Ustaw” 2015, poz. 249. 